the patient is unlikely to derive much encouragement from " investigations with radioisotopes of sodium, potassium, and chlorine show that movements of the ions through capillary walls and cell membrane are best explained in terms of active transfer ", nor may he altogether share the view that " the diabetic state gives rise to interesting organic changes ".

The book is poorly written, and when the author leaves the clinical field his text consists of snippets from the literature with little attempt to evaluate the material or to weave it into a coherent whole. It is not, therefore, suitable for the internist.

Of the six illustrations purporting to show pathological changes in the retina, only one (Fig. 10) could be accepted as demonstrating the claims of the legend, and the simplified diagrams of metabolic pathways are probably of little value to the reader for whom they were designed. The author presents no original data and his suggestions for future research, such as "Nutrition and disease and how they affect the body tissues", are so all-embracing and vast in scope as to appal the keenest research worker seeking here for inspiration. It is unfortunate that the book cannot be recommended, for it is beautifully produced and singularly free from printer's errors.

Viral and Rickettsial Diseases of the Skin, Eyes, and Mucous Membranes of Man. By H. Blank and G. RaKe. 1955. Pp. 285, 63 figs, 6 col. pl. Churchill, London. (60s.).

In a short text the authors have attempted to give an outline of the main viral infections occurring in these sites in man, with the inevitable result that many diseases which might have been mentioned are omitted. However, those conditions with which the book deals are presented in a readable manner and should prove instructive to those requiring an introduction to the subject.

A serious criticism of the work is the arrangement and classification of the material. Thus there seems little merit in separating Psittacosis from the remainder of Chlamydozoacae, while it is unusual to find dengue and infectious mononucleosis included with the exanthemata.

The book is extremely well produced and the illustrations are of a very high standard. A series of the references considered to be of greatest importance is added at the end of each section.

\title{
NOTES
}

\section{INTERNATIONAL Council of OphThaLmology}

The following were present at a meeting held in Paris on May 7, 1955: Duke-Elder (President), Berens (Vice-President), Hartmann (Secretary), Amsler (Treasurer), Bietti (International Organization against Trachoma), Franceschetti (Association for the Prevention of Blindness), Samuels (President of the last Congress), Coppez (President of the next Congress), Arruga (Spain), Charamis (Greece), Palomino Dena (Mexico), Paufique (France), Thiel (Germany), Weve (Holland).

Apart from dealing with current business, the following are the most important decisions taken by the Council.

1. Index Ophthalmologicus.-In accordance with the Statutes of the Council, an Index Ophthalmologicus had been published at the time of the International Congress in 1954. The sale of the Index had, however, up to the present been very slow, involving the Council in considerable expense. It was thought that this was due to the fact that it was insufficiently known. The Index contains the names and addresses of ophthalmologists in most countries of the world and information on hospitals, journals, and ophthalmological societies in these countries. It may 